\title{
Aplikasi Analisis Korespondensi Berganda terhadap Pemetaan Perkembangan Pembangunan Kota Ambon
}

\author{
Y. A. Lesnussa, H. Kelian, E.R. Persulessy, R. J. DJAMi, M.W. TAlakuA \\ Jurusan Matematika FMIPA Universitas Pattimura Ambon \\ Jl. Ir. M. Putuhena, Kampus-Poka, Ambon, Maluku 97233 \\ Email: Emmykelian08@gmail.com; yopi_a_lesnussa@yahoo.com
}

\begin{abstract}
ABSTRAK
Penelitian ini bertujuan untuk mengetahui peta persepsi indikator pembangunan di kota Ambon dengan menggunakan Analisis Korespondensi Berganda. Dimana metode ini menganalisis kategori dari beberapa indikator pembangunan antara lain, banyaknya fasilitas Pendidikan, banyaknya fasilitas Kesehatan, penduduk miskin dan banyaknya Objek Wisata yang ada di kota Ambon. Dari hasil penelitian diperoleh kesimpulan bahwa kecamatan yang melalui jalan pusat kota Ambon menunjukan adanya peningkatan sarana pendidikan, sarana Kesehatan dan juga penduduk miskin, sedangkan untuk indikator Objek Wisata sendiri terjadi peningkatan pada kecamatan yang tidak dilalui Jalan Pusat Kota.
\end{abstract}

Kata Kunci: Analisis Korespondensi Berganda, Indikator Pembangunan.

\section{PENDAHULUAN}

Pembangunan daerah merupakan suatu usaha yang sistematik dari berbagai pelaku, baik umum, pemerintah, swasta maupun kelompok masyarakat lainnya pada tingkatan berbeda untuk menghadapi saling ketergantungan dan keterkaitan aspek fisik, sosial ekonomi dan aspek lingkungan sehingga peluang baru untuk Meningkatkan kesejahteraan masyarakat. Perkembangan pembangunan di wilayah kota Ambon pada hakekatnya bertujuan untuk mensejahterakan masyarakat. Faktor-faktor yang turut mempengaruhi perkembangan pembangunan di suatu daerah sabagai suatu ukuran untuk menggambarkan kemajuan pembangunan daerah khususnya kota Ambon sangatlah variatif dalam hal ini peneliti tertarik untuk menelaah lebih lanjut tentang beberapa faktor seperti banyaknya fasilitas pendidikan, banyaknya fasilitas kesehatan, banyaknya objek wisata dan jumlah penduduk miskin serta letak strategis jalan pusat kota yang ada di lima kecamatan di kota Ambon.

Dari permasalahan di atas diperlukan suatu metode statistik untuk mengidentifikasi perkembangan pembangunan kecamatan-kecamatan yang ada di kota Ambon dengan menggunkan analisis korespondensi. Analisis korespondensi merupakan salah satu teknik yang dapat digunakan untuk melihat keterkaitan tersebut. Analisis korespondensi adalah salah satu teknik dalam Statistika Multivariat yang merupakan teknik reduksi data dan pemetaan persepsi. Salah satu tujuan analisis korespondensi adalah untuk melihat keterkaitan atau kedekatan suatu kategori pada suatu peubah terhadap kategori peubah lainnya. Oleh karena itu dilakukan penelitian dengan judul "Aplikasi Analisis Korespondensi Berganda Terhadap Pemetaan Perkembangan Pembangunan Kota Ambon”.

\section{TINJAUAN PUSTAKA}

Analisis korespondensi ditemukan dan dikembangkan pertama kali tahun 1960-an oleh JeanPaul, Benzecri dkk di Perancis. Analisis ini diartikan sebagai teknik penyajian data antar baris, antar kolom, dan antar baris dan antar kolom tabel kontingensi dua arah yang kemudian dapat diperluas untuk tabel kontingensi multi arah pada suatu ruang vektor berdimensi kecil dan optimal. Analisis ini juga didesain untuk digunakan dalam pembangunan pengelompokkan yang mewakili data frekuensi. Menurut Greenacre (1984), analisis yang mempelajari hubungan 
antara dua arah atau lebih variabel dengan memperagakan baris dan kolom secara serempak dari tabel kontingensi dua arah dalam ruang vektor berdimensi rendah (dua).

Analisis korespodensi merupakan salah satu teknik statistika yang digunakan untuk mengetahui hubungan (korespondensi) antar variabel. Variabel yang dimaksud adalah antara variabel terikat dengan variabel bebas. Adapun skala data dari antar variabel tersebut adalah skala nominal, sehingga data dinyatakan dalam bentuk crosstabs. Dengan analisis korespondensi, dapat ditelaah lebih lanjut kedekatan antar variabel.

analisis korespondensi menyatakan bahwa penyajian data secara grafis mempunyai beberapa kelebihan di antaranya dapat menyingkat data, mudah diinterpretasikan karena dapat menyederhanakan aspek data dengan menyajikan data secara visual (greencre, 1984). greenacre (1984) menyatakan analisis korespondensi adalah teknik analisis data yang memperagakan baris dan kolom secara serempak dari suatu tabel kontingensi dwi arah dalam ruang vektor berdimensi rendah (dua).

\section{Metode Analisis Korespondensi}

Analisis Korespondensi merupakan prosedur grafis untuk menggambarkan suatu hubungan pada tabel frekuensi (Johnson, 2002). Analisis Korespondensi sebagai teknik yang memperagakan baris dan kolom matriks data pada (Tabel Kategori Variabel Dan Matriks Indikator). Analisis Korespondensi adalah teknik untuk menyajikan baris dan kolom dari suatu matriks data yang merupakan tabel kontingensi dua arah.

Analisis korespondensi mempunyai kesamaan konsep dengan analisis komponen utama dan biplot, yaitu dapat mereduksi data kedalam ruang berdimensi yang lebih rendah berdasarkan akar ciri terbesar untuk mempertahankan informasi optimum. Analisis Korespondensi menggambarkan kedekatan profil antar kategori pada tiap gugus data dalam bentuk grafik atas dasar posisi relatif yang menunujukan jarak antar kategori. Perhitungan jarak dengan menggunakan jarak khi-kuadrat yang dirumuskan sebagai berikut :

Jarak kolom ke-j' adalah

$$
d^{2}{ }_{\left(i, i^{\prime}\right)} \sum_{j=1} \frac{1}{f_{j}}\left(\frac{f_{i j}}{f_{i .}}-\frac{f_{i^{\prime} j}}{f_{i^{\prime} .}}\right)^{2}
$$

$$
d^{2}{ }_{\left(j, j^{\prime}\right)} \sum_{i=1} \frac{1}{f_{i}}\left(\frac{f_{i j}}{f_{. j}}-\frac{f_{i^{\prime} j}}{f_{\cdot j^{\prime}}}\right)^{2}
$$

dimana: $i=1,2, \ldots . n$ dan $j=1,2, \ldots, p$

$\mathrm{F}_{\mathrm{ij}}=$ frekuensi relatif sel baris ke- $i$ kolom ke- $j$

$F_{i .}=$ total frekuensi relatif baris ke- $i$

$\mathrm{f} . \mathrm{j}=$ total frekuensi relatif kolom ke- $j$

Konsep jarak khi-kuadrat adalah jika dua baris yang identik (penyebaran frekuensi relatif masing-masing kategori pada kolom bernilai sama) digabung maka jarak antar kolom tidak berubah, dan jika dua kolom yang identik digabungkan maka jarak antar baris tidak berubah.

Misalkan $\mathrm{N}$ adalah matriks data berukuran $(\mathrm{IxJ})$, yang dinotasikan $\mathrm{N}_{(\mathrm{ixj})}=\left[\mathrm{n}_{\mathrm{ij}}\right], \mathrm{n}_{\mathrm{ij}} 0$. Dengan $\mathrm{P}$ merupakan matriks korespondensi yang diperoleh dengan membagi setiap unsur matriks $\mathrm{N}$ dengan total semua matriks $\mathrm{N}$, yaitu :

$\mathrm{P}=(1 / \mathrm{n}) \mathrm{N}$

dimana $\mathrm{n} . . \underline{1} \underline{1} \mathrm{~N} \underline{1}$

Misalkan $\mathrm{D}_{\mathrm{r}}$ adalah matriks diagoonal dari $\mathrm{r}$ yang berukuran (IxJ) yang dinotasikan $\mathrm{D}_{\mathrm{r}}(\mathrm{IxJ})$ yang dinotasikan $\mathrm{D}_{\mathrm{c}}$ adalah matriks diagonal dari $\underline{\mathrm{c}}$ yang berukuran (IxJ) yang dinotasikan $\mathrm{D}_{\mathrm{c}}(\mathrm{IxJ})=\operatorname{diag}(\underline{\mathrm{c}})$ dengan $\underline{\mathrm{r}}=\mathrm{p} \underline{1}$ dan $\underline{\mathrm{c}}=\mathrm{p}$ ' $\underline{1}$. Maka matriks profil baris dan matriks kolom adalah :

$\mathrm{R}=\mathrm{D}_{\mathrm{r}^{-1} \mathrm{P}}$, dan

$\mathrm{C}=\mathrm{D}^{-1} \mathrm{P}^{\prime}$

Koordinat dari baris dan kolomnya ditentukan dengan menggunakan PNSU (Penguraian Nilai Singular Umum) atau Generalized Singular Value Decomposition (GSVD) pada matriks (P-rc') adalah : 
$\left(\mathrm{P}-\underline{\mathrm{rc}^{\prime}}\right)=\mathrm{AD}_{\mathrm{a}} \mathrm{B}^{\prime}$

Dimana A'Dr $A=I$ dan $B^{\prime} D_{c}^{-1} B=I$

$\mathrm{D}_{\mathrm{a}}$ : matriks diagonal nilai positif dari nilai singular a $1, \mathrm{a}_{2, \mathrm{a}}, \ldots, \mathrm{a}_{\mathrm{k}}$.

$\mathrm{k}$ : pangkat dari matriks $\mathrm{P}$

A : matriks singular kiri

B : matriks singular kanan

Sehingga koordinat dari profil baris dan kolom masing-masing adalah :

$\mathrm{F}=\mathrm{D}_{\mathrm{r}^{-1}} \mathrm{AD}$ a dan $\mathrm{G}=\mathrm{D}_{\mathrm{c}}^{-1} \mathrm{BD}$ a

Untuk interpertasi titik-titik pada gambar menggunakan nilai kontribusi relatif. Kontribusi mutlak ini menginformasikan proporsi keragaman yang dapat diterangkan oleh masing-masing titik terhadap sumbu utama yang terbetuk. Rumus perhitungan kontribusi mutlak (KM) adalah sebagai berikut :

$$
K M_{i}=\frac{m x K T S_{i k}^{2}}{\alpha_{k}^{2}}
$$

dimana : $\mathrm{m}$ adalah massa atau frekuensi relatif tiap kategori $\mathrm{kts}_{\mathrm{ik}}{ }^{2}$ adalah koordinat titk ke-i pada sumbu ke-k, dan $\mathrm{a}_{\mathrm{k}}$ adalah nilai singular ke-k. sedangkan rumus perhitungan kontribusi relatif $(\mathrm{kr})$ sebagai berikut :

$$
K R_{i}=\operatorname{Cos}^{2}\left(\theta_{k}\right)=\frac{K T S_{i k}^{2}}{\sum_{k=1} K T S \alpha_{i k}^{2}}
$$

kontribusi relatif (kuadrat cosinus menurut lebart et all, 1984) digunakan untuk melihat proporsi keragaman yang dapat diterangkan oleh sumbu utama terhadap titik-titik tersebut.

\section{Sifat-sifat Dasar Analisis Korespondensi}

Analisis ini juga mempunyai beberapa sifat dasar yang perlu diperhatikan yaitu:

1. Dipergunakan untuk data non-metrik dengan skala pengukuran nominal dan ordinal.

2. Bisa dipergunakan untuk hubungan non-linier.

3. Tidak ada asumsi tentang distribusi.

4. Tidak ada model yang dihipotesiskan.

5. Sebagai salah satu metode dalam eksplorasi data yang hasil akhirnya dapat berupa hipotesis yang prlu diuji lebih lanjut.

Salah satu teknik struktur pengelompokkan atau reduksi data.

\section{Kelebihan dan Kekurangan Analisis Korespondensi}

Analisis Korespondensi juga memiliki kelebihan dan kekurangan bila dibandingkan dengan analisis lainya, yaitu:

1. Kelebihan

1) Sangat tepat untuk menganalisis data variabel kategori ganda yang dapat digambarkan secara sederhana dalam data tabulasi silang.

2) Tidak hanya menggambarkan hubungan antar baris dengan kolom tetapi juga antar kategori dalam setiap baris dan kolom.

3) Memberikan tampilan grafik gabungan dari kategori baris dan kolom dalam satu gambar yang berdimensi sama.

4) cukup fleksibel untuk digunakan dalam data matrik berukuran besar.

2. Kekurangan

Analisis ini tidak cocok untuk pengujian hipotesis tetapi sangat tepat untuk eksplorasi data. dan kurang tepat bila dipakai untuk analisis data kuantitatif. 


\section{METODOLOGI PENELITIAN}

Metode yang digunakan dalam penelitian ini adalah metode deskriptif dengan pemetaan persepsi untuk melihat perbandingan karakteristik suatu daerah (kecamatan) terhadap daerah itu sendiri. Data yang digunakan yaitu data sekunder dari Badan Pusat Statistik kota Ambon tahun 2013 mengenai empat variabel hasil pembangunan di kecamatan-kecamatan yang ada di kota Ambon yaitu :

1. Banyaknya fasilitas Pendidikan

2. Banyaknya fasilitas Kesehatan

3. Banyaknya Penduduk Miskin

4. Banyaknya Objek Wisata

Satu variabel biner berupa (Letak Strategis Pusat Kota) dimana kecamatan yang di lalui jalan pusat kota diberikan kode (1) dan kecamatan yang tidak dilalui jalan pusat kota diberikan kode (0). Dari data, terlebih dahulu dibuat kategori variabel indikator berdasarkan aturan Sturges sebagai berikut.

Tabel 1. Kategori variabel indikator pembangunan

\begin{tabular}{|c|c|c|}
\hline Variabel & Nama Variabel & Kategori \\
\hline $\mathrm{X} 1$ & Fasilitas Pendidikan & $\begin{array}{l}\mathrm{X} 11=\text { pendidikan }<20 \\
\mathrm{X} 12=20 \leq \text { pendidikan }<40 \\
\mathrm{X} 13=40 \leq \text { pendidikan }<60 \\
\mathrm{X} 14=\text { pendidikan } \geq 60\end{array}$ \\
\hline $\mathrm{X} 2$ & Fasilitas Kesehatan & $\begin{array}{l}\mathrm{X} 21=\text { kesehatan }<50 \\
\mathrm{X} 22=50 \leq \text { kesehatan }<100 \\
\mathrm{X} 23=100 \leq \text { kesehatan }<150\end{array}$ \\
\hline X3 & Objek Wisata & $\begin{array}{l}\text { X31 }=\text { objek wisata }<5 \\
\text { X32 }=10 \leq \text { objek wisata }<15 \\
\text { X33 }=15 \leq \text { objek wisata } \geq 20\end{array}$ \\
\hline $\mathrm{X} 4$ & Penduduk miskin & $\begin{array}{l}\mathrm{X} 41=\text { penduduk miskin }<1000 \\
\mathrm{X} 42=1500 \leq \text { penduduk miskin }<2000 \\
\mathrm{X} 43=2000 \leq \text { penduduk miskin } \geq 2500\end{array}$ \\
\hline X5 & Letak Strategis & $\begin{array}{l}\text { X51 = Melalui Jalan Pusat Kota } \\
\text { X52= Tidak Melalui Jalan Pusat Kota }\end{array}$ \\
\hline
\end{tabular}

Berdasarkan Tabel 1 di atas diperoleh indikator variabel penelitian (Tabel 2). 
Tabel 2. Indikator variabel penelitian

\begin{tabular}{|c|c|c|c|c|c|c|c|c|c|c|c|c|c|c|c|c|c|c|c|}
\hline \multirow{2}{*}{ No } & \multirow{2}{*}{ KECAMATAN } & \multicolumn{4}{|c|}{$\mathbf{X}_{1}$} & \multicolumn{4}{|c|}{$\mathbf{X}_{2}$} & \multicolumn{4}{|c|}{$\mathbf{X}_{3}$} & \multicolumn{4}{|c|}{$\mathbf{X}_{4}$} & \multicolumn{2}{|r|}{$\mathbf{X X}$} \\
\hline & & $\mathbf{x}_{11}$ & $\mathbf{x}_{12}$ & $\mathbf{x}_{13}$ & $\mathbf{x}_{14}$ & $\mathbf{x}_{21}$ & $\mathbf{x}_{22}$ & $\mathbf{x}_{23}$ & $\mathbf{x} 24$ & $\mathbf{x}_{31}$ & $\mathbf{x}_{32}$ & $\mathbf{x} 33$ & $\mathbf{x}_{34}$ & $\mathbf{x} 41$ & $\mathbf{x} 42$ & $\mathbf{x} 43$ & $\mathbf{x} 44$ & $\mathbf{x}_{51}$ & $\mathbf{x} 52$ \\
\hline 1. & Nusaniwe & 0 & 0 & 0 & 1 & 0 & 0 & 1 & 0 & 0 & 0 & 0 & 1 & 0 & 0 & 0 & 1 & 1 & 0 \\
\hline 2 & Sirimau & 0 & 0 & 0 & 1 & 0 & 0 & 1 & 0 & 0 & 0 & 1 & 0 & 0 & 0 & 0 & 1 & 1 & 0 \\
\hline 3 & T.Ambon & 0 & 0 & 1 & 0 & 0 & 1 & 0 & 0 & 0 & 0 & 1 & 0 & 0 & 0 & 1 & 0 & 0 & 1 \\
\hline 4 & T.A. Baguala & 0 & 0 & 1 & 0 & 0 & 1 & 0 & 0 & 1 & 0 & 0 & 0 & 0 & 0 & 0 & 1 & 0 & 1 \\
\hline 5 & $\begin{array}{l}\text { Leitimur } \\
\text { selatan }\end{array}$ & 1 & 0 & 0 & 0 & 1 & 0 & 0 & 0 & 0 & 0 & 0 & 1 & 1 & 0 & 0 & 0 & 0 & 1 \\
\hline
\end{tabular}

untuk dapat menganalisis hubungan antara kategori baris dan kolom di gunakan metode analisis koespondensi berganda dengan bantuan software minitab 16.

Gambar 1 merupakan kerangka metode penelitian dalam menganalisis variabel indikator pembangunan.

Gambar 1. Flowchart untuk Analisis Korespondensi

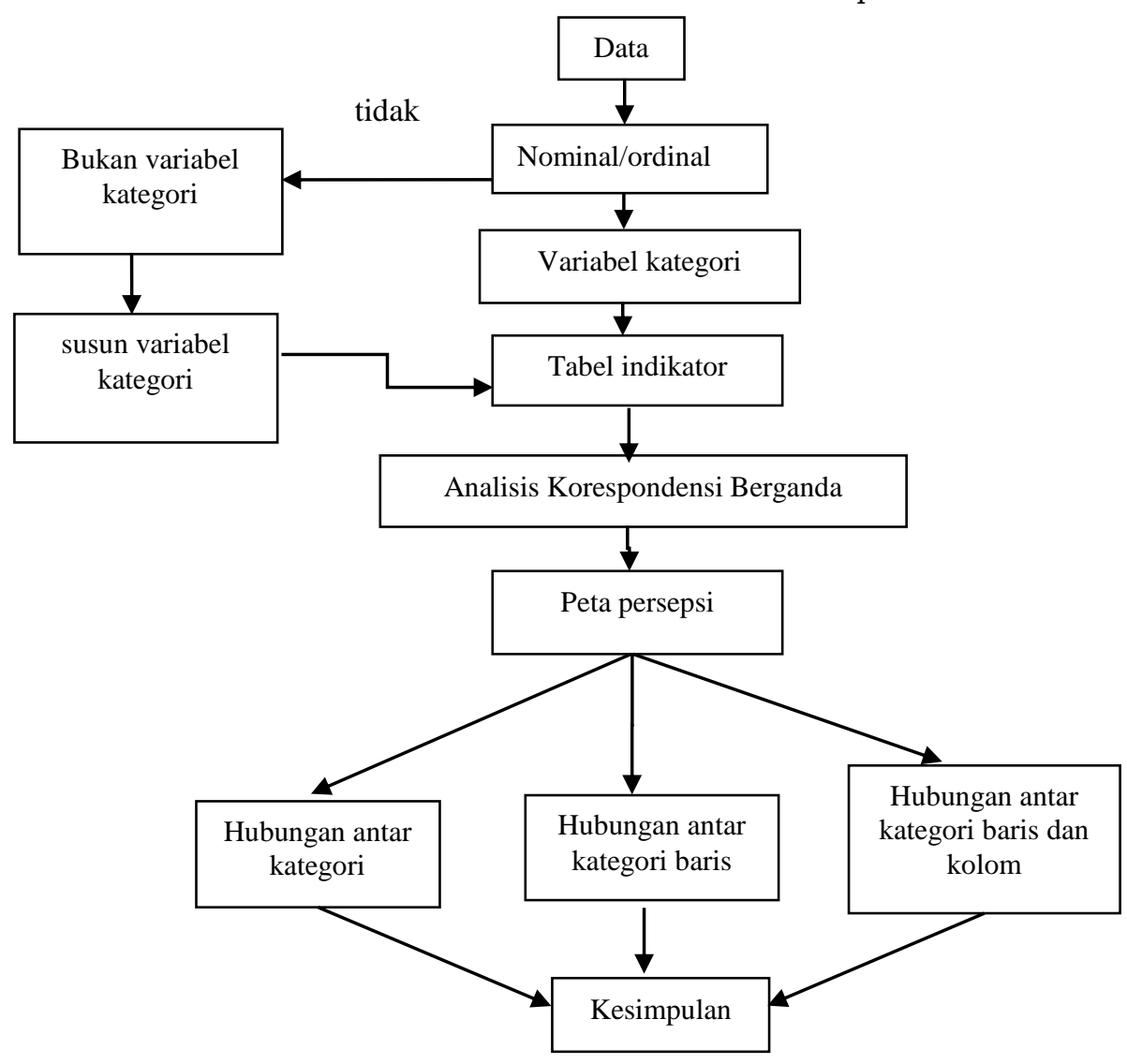

\section{HASIL DAN PEMBAHASAN}

Kota Ambon dalam posisi sebagai ibu kota dari Provinsi Maluku sekaligus berfungsi sebagai pusat kegiatan dengan berbagai aktifitas Sosial, Ekonomi, Pemerintahan serta Pendidikan 
Tinggi di Provinsi Maluku yang berpengaruh pada pertumbuhan penduduk termasuk pula migrasi dari daerah-daerah sekitar, kondisi ini terlihat pada laju pertumbuhan penduduk dan tingkat kepadatan penduduk yang cenderung meningkat di kota Ambon. Penduduk kota Ambon berdistribusi di 5 kecamatan di antaranya :

1. Kecamatan Nusaniwe

2. Kecamatan Sirimau

3. Kecamatan Teluk Ambon

4. Kecamatan Teluk Ambon Baguala

5. Kecamatan Leitimur Selatan.

Dimana dari 5 kecamatan tersebut, ada 2 kecamatan yang dilalui oleh jalan

pusat kota yaitu kecamatan Nusaniwe dan kecamatan Sirimau. Sedangkan 3 kecamatan lainnya yaitu kecamatan Teluk Ambon, Teluk Ambon Baguala dan Leitimur Selatan tidak dilalui oleh jalan pusat kota.

Dengan menggunakan analisis korespondensi multipel pada software minitab 16 diperoleh hasil analisis sebagai berikut :

\section{Analysis of Indicator Matrix}

$\begin{array}{ccccl}\text { Axis } & \text { Inertia } & \text { Proportion } & \text { Cumulative } & \text { Histogram } \\ 1 & 0.7697 & 0.4618 & 0.4618 & * * * * * * * * * * * * * * * * * * * * * * * * * * * * * \\ 2 & 0.5890 & 0.3534 & 0.8152 & * * * * * * * * * * * * * * * * * * * * * \\ 3 & 0.2443 & 0.1466 & 0.9618 & * * * * * * * * * \\ 4 & 0.0637 & 0.0382 & 1.0000 & * *\end{array}$

Total 1.6667

Berdasarkan analisis indikator matriks di atas diperoleh hasil analisis yang terbagi menjadi 4 dimensi dalam analisis korespondensi sebagai berikut:

1) Dengan menggunakan axis pertama saja (1 dimensi) maka model dalam analisis ini dilihat dari kolom Comulative di axis pertama, yang hanyamampu menjelaskan variasi sebesar $46,18 \%$.

2) Jika menambahkan axis ke 2 maka dapat dilihat dari Propotion terdapat tambahan 35,34\% sehingga dengan 2 dimensi sudah mampu menjelaskan variasi sebesar 81,52\%.

3) Jika menambahkan axis ke 3 maka dapat dilihat dari Propotion terdapat tambahan 14,66\% sehingga dengan 3 dimensi sudah mampu menjelaskan variasi sebesar 96,18 \%.

4) Jika menambahkan axis ke 4 maka dapat dilihat dari Propotion terdapat tambahan 6,37\% sehingga dengan 4 dimensi sudah mampu menjelaskan semua variasi yaitu sebesar $100 \%$.

Dalam menentukan jumlah dimensi, penambahan yang dilakukan sampai jumlah dimensi maksimum mampu meningkatkan kemampuan model dalam menjelaskan variasi yaitu besarnya keragaman yang dilihat oleh masing-masing komponen. Namun perlu diperhatikan juga bahwa penambahan jumlah dimensi yang digunakan akan berpengaruh terhadap peningkatan kekomplekan untuk menginterpretasikan hasilnya. Oleh karena itu, dalam permasalahan ini kita dapat menggunakan 2 dimensi saja yang ternyata telah mampu menjelaskan variasi sebesar $81,52 \%$.

\begin{tabular}{|c|c|c|c|c|c|c|c|}
\hline ID & Name & Qual & Mass & Inert & Coord & Corr & Contr \\
\hline 1 & $\mathrm{FP}<20$ & 0.983 & 0.033 & 0.080 & 0.914 & 0.209 & 0.036 \\
\hline 2 & $20 \leq \mathrm{FP}<40$ & 0.985 & 0.067 & 0.060 & 0.765 & 0.391 & 0.051 \\
\hline 3 & $40 \leq \mathrm{FP}<60$ & 0.999 & 0.067 & 0.060 & -1.222 & 0.996 & 0.129 \\
\hline 4 & $\mathrm{FP} \geq 60$ & 0.983 & 0.033 & 0.080 & 0.914 & 0.209 & 0.036 \\
\hline 5 & $\mathrm{FK}<50$ & 0.985 & 0.067 & 0.060 & 0.765 & 0.391 & 0.051 \\
\hline 6 & $50 \leq \mathrm{FK}<100$ & 0.999 & 0.067 & 0.060 & -1.222 & 0.996 & 0.129 \\
\hline 7 & $100 \leq F K<150$ & 0.320 & 0.033 & 0.080 & 0.714 & 0.128 & 0.022 \\
\hline 8 & $150 \leq \mathrm{FK} \geq 200$ & 0.258 & 0.067 & 0.060 & -0.206 & 0.028 & 0.004 \\
\hline
\end{tabular}




$\begin{array}{rlrrrrrr}9 & \text { OW }<5 & 0.717 & 0.067 & 0.060 & -0.151 & 0.015 & 0.002 \\ 10 & 10 \leq 0 W<15 & 0.983 & 0.033 & 0.080 & 0.914 & 0.209 & 0.036 \\ 11 & \text { OW } \geq 15 & 0.422 & 0.033 & 0.080 & 0.817 & 0.167 & 0.029 \\ 12 & \text { PM<1000 } & 0.592 & 0.100 & 0.040 & -0.577 & 0.499 & 0.043 \\ 13 & 1500 \leq \text { PM<2000 } & 0.999 & 0.100 & 0.040 & 0.815 & 0.996 & 0.086 \\ 14 & \text { PM } \geq 2000 & 0.999 & 0.067 & 0.060 & -1.222 & 0.996 & 0.129 \\ 15 & \text { MJPK } & 0.999 & 0.067 & 0.060 & -1.222 & 0.996 & 0.129 \\ 16 & \text { TMJPK } & 0.999 & 0.100 & 0.040 & 0.815 & 0.996 & 0.086\end{array}$

$\begin{array}{clrcc}\text { ID } & \text { Name } & \text { Coord } & \text { Corr } & \text { Contr } \\ 1 & \mathrm{FP}<20 & -1.759 & 0.774 & 0.175 \\ 2 & 20 \leq \mathrm{FP}<40 & 0.944 & 0.594 & 0.101 \\ 3 & 40 \leq \mathrm{FP}<60 & -0.065 & 0.003 & 0.000 \\ 4 & \mathrm{FP} \geq 60 & -1.759 & 0.774 & 0.175 \\ 5 & \mathrm{FK}<50 & 0.944 & 0.594 & 0.101 \\ 6 & 50 \leq \mathrm{FK}<100 & -0.065 & 0.003 & 0.000 \\ 7 & 100 \leq \mathrm{FK}<150 & 0.878 & 0.193 & 0.044 \\ 8 & 150 \leq \mathrm{FK} \geq 200 & 0.587 & 0.230 & 0.039 \\ 9 & \mathrm{OW}<5 & -1.026 & 0.702 & 0.119 \\ 10 & 10 \leq \mathrm{OW}<15 & -1.759 & 0.774 & 0.175 \\ 11 & \mathrm{OW} \geq 15 & 1.011 & 0.255 & 0.058 \\ 12 & \mathrm{PM}<1000 & 0.249 & 0.093 & 0.011 \\ 13 & 1500 \leq \mathrm{PM}<2000 & 0.043 & 0.003 & 0.000 \\ 14 & \mathrm{PM} \geq 2000 & -0.065 & 0.003 & 0.000 \\ 15 & \mathrm{MJPK} & -0.065 & 0.003 & 0.000 \\ 16 & \mathrm{TMJPK} & 0.043 & 0.003 & 0.000\end{array}$

Berdasarkan Kontribusi Kolom di atas di peroleh hasil analisis sebagai berikut:

1) Coord atau koordinat menggambarkan letak dari masing-masing variabel dalam penggambaran peta persepsi-nya dimana Component 1 sebagai sumbu-x dan Component 2 sebagai sumbu-y.

2) Corr merupakan kontribusi dari masing-masing komponen terhadap inersia masingmasing variabel.

3) Cont merupakan kontribusi dari masing-masing variabel terhadap sumbu inersia masingmasing component.

4) Qual atau quality atau kualitas merupakan proporsi inersia masing-masing variabel yang diberikan oleh semua komponen.

5) Mass atau massa merupakan proporsi dari masing-masing variabel terhadap total frekuensi.

6) Inert merupakan proporsi dari inersia yang diberikan oleh masing-masing variabel.

\section{Analisis Plot}

Dari Minitab 16 diperoleh Plotting tiap variabel kategori sebagai berikut: 


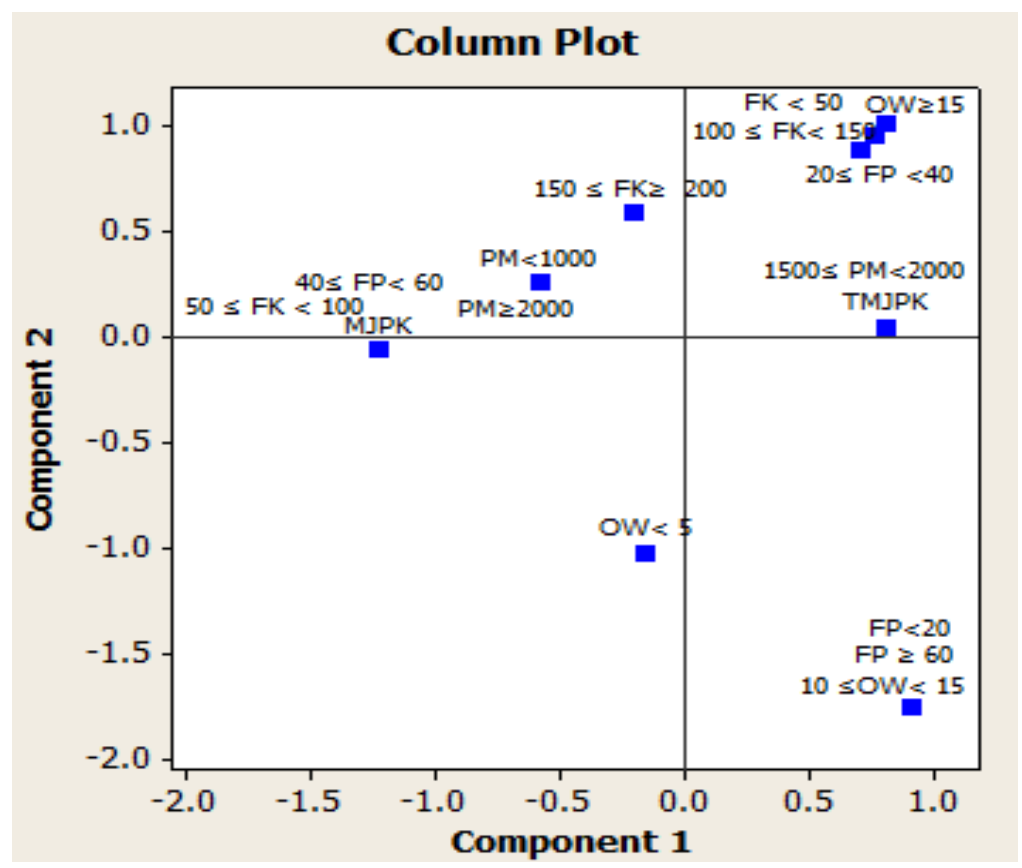

Gambar 3. Ploting kategori variabel indikator

Dari Gambar 2 di atas diperoleh analisis sebagai berikut:

TMJPK (Tidak Melalui Jalan Pusat Kota) merupakan variabel indikator pembagunan untuk melihat variabel kategori yang ada di kecamatan yang tidak dilalui jalan pusat kota. Dari hasil analisis plot di atas dapat dilihat pada dimensi (I) dimana variabel kategori $20 \leq \mathrm{FP}<40$, $\mathrm{FK}<50$, $100 \leq \mathrm{FK}<150$, $\geq 15$, dan $1500 \leq \mathrm{PM}<2000$ kategori variabel tersebut saling memiliki hubungan karena berada pada dimensi yang sama dan dipengaruhi oleh variabel indikator letak strategis. Variabel indikator pembangunan letak strategis salah satunya adalah MJPK (Melalui Jalan Pusat Kota) dimana pada variabel ini dapat dilihat variabel kategori apa saja yang berada pada kecamatan-kecamatan yang di dilalui Jalan Pusat Kota. Berdasarkan hasil plot diatas variabel $\mathrm{PM} \geq 2000,50 \leq \mathrm{FK}<100,40 \leq \mathrm{FP}<60$, dan kategori $\mathrm{PM}<1000$ serta jumlah fasilitas kesehatan dengan kategori $150 \leq$ FK $\geq 200$. berada pada dimensi yang sama yaitu Pada dimensi (II) sehingga ke-5 kategori variabel tersebut memiliki hubungan satu sama lain yang di pengaruhi oleh indikator letak strategis.

Pada dimensi (III) hanya terdapat 1 variabel kategori yaitu $\mathrm{OW}<5$ dan tidak dipengaruhi oleh indikator apapun.

Kecamatan dengan fasilitas pendidikan $<20$ serta $\geq 60$, serta obyek wisata $10 \leq$ OB $<15$ mempunyai hubungan erat satu sama lain karena berada pada satu dimensi yang sama yaitu dimensi (IV) dan tidak dipengaruhi oleh indikator apapun.

\section{KESIMPULAN}

Analisis korespondensi memetakan letak dari masing-masing variabel indikator pembangunan, yang memiliki hubungan antar variabel satu dengan yang lain serta memberikan kontribusi terhadap pembangunan kota Ambon. Keberadaan Jalan Pusat Kota yang merupakan letak strategis sebagai salah satu indikator pembangunan kecamatan di kota Ambon menunjukan adanya peningkatan sarana pendidikan, sarana kesehatan, dan juga penduduk miskin di kota Ambon, hal ini dikarenakan sebagian besar penduduk tinggal di wilayah perkotaan sedangkan di wilayah yang tidak dilalui jalan pusat kota menunjukan adanya peningkatan objek wisata karena di wilayah tersebut pada umumnya banyak terdapat sumber daya alam dan unsur yang alami serta indah untuk dijadikan pendukung suatu objek wisata. 


\section{DAFTAR PUSTAKA}

Arsyasita, dkk. (2012). Analisis Korespondensi Data Kejadian Di Polsek Simokerto Pada Bulan Januari-Desember (2010). Surabaya.

Buku Putih Sanitasi Kota Ambon 2012.

Dillon, W.R.; Matthew G., 1984. Multivariate Analysis: Methods and Application, John Willey and Sons Inc, New York.

Gumgum Darmawan. (2009). Aplikasi Analisis Korespondensi Untuk Melihat Perkembngan Wilayah di Kabupaten Sumedang.

Greenacre,M.J. (1984). Theory and Applications of Correspondence Analysis. NewYork: Academic Press INC.

Iqbal Hasan. (2003). Pokok-Pokok Materi Statistik 1 (Statistik Deskriptif) (edisi kedua). Jakarta: PT Bumi Aksara.

Ridwan, Sunarto.H. (2010). Pengantar Statistik Untuk Penelitian Pendidikan, Sosial, Ekonomi, Komunikasi, dan Bisnis. Bandung: Alyabeta.

Supranto.J. (2008). Statistika Teori dan Aplikasi Edisi Ketujuh. Jakarta: PT. Gelora Aksara Pratama. 